\title{
Optimizing delivery of HIV-1 conserved region-derived immunogen for induction of $T$ and $B$ cell responses in rhesus macaques
}

\author{
M Rosario, G Koopman, A Mbewe-Mvula, ML Knudsen, ED Quakkelaar, N Borthwick, R Wagner, DA Price, \\ P Liljestrom, CJ Melief, JW Drijfhout, S Colloca, A Nicosia, T Hanke*
}

From AIDS Vaccine 2012

Boston, MA, USA. 9-12 September 2012

\section{Background}

The complexity of candidate HIV-1 vaccine formulations is increasing due to extreme challenges faced when trying to prevent or control HIV-1 infection.

\section{Methods}

Immunogen HIVconsv based on the most conserved regions of the HIV-1 proteome was used to explore combinations of seven distinct vaccines modalities in heterologous prime-boost regimens delivered to rhesus macaques to optimize induction of $\mathrm{T}$ cell and antibody responses. These include plasmid DNA (P), Semliky Forest virus replicons delivered as DNA (DREP; D) or virus particles (VREP; V), modified vaccinia virus Ankara (MVA; M), adenoviruses of human (HAdV-5; A) and chimpanzee origin (ChAdV-63; C) and adjuvanted synthetic long peptides (SLP; S).

\section{Results}

A number of observations were made. Thus, a very potent combination for induction of HIV-1-specific T cells was an adenovirus vector (A or C) followed by poxvirus $\mathrm{M}$. $\mathrm{S}$ boost broadened $\mathrm{T}$ cell responses, but did not prime $\mathrm{T}$ cells efficiently. $\mathrm{D}$ was a stronger prime than P. PPP was the best prime for T cells, while PSS was best for induction of antibodies. Even very complex regimen PPPAMSSCMV continued to recruit new $\mathrm{T}$ cell clones into the response to a single epitope, although a ceiling for immunodominant responses was reached; subdominant responses could be boosted up to the last $\mathrm{V}$ delivery. Finally, PPSS, but not SSSS could protect 2/6 animals from SIVmac251 acquisition.

University of Oxford, Oxford, UK

\section{Conclusion}

These results will guide initial design of human trials. So far, human studies in Oxford testing CM, PPPCM and PPPMC regimen concur with observations made in rhesus macaques.

Published: 13 September 2012

\section{doi:10.1186/1742-4690-9-S2-P31}

Cite this article as: Rosario et al:: Optimizing delivery of HIV-1 conserved region-derived immunogen for induction of $\mathrm{T}$ and $\mathrm{B}$ cell responses in rhesus macaques. Retrovirology 2012 9(Suppl 2):P31.

\section{Submit your next manuscript to BioMed Central and take full advantage of: \\ - Convenient online submission \\ - Thorough peer review \\ - No space constraints or color figure charges \\ - Immediate publication on acceptance \\ - Inclusion in PubMed, CAS, Scopus and Google Scholar \\ - Research which is freely available for redistribution

